\title{
沿岸航海の安全支援のためのカーナビの利用と 航海情報に関する研究
}

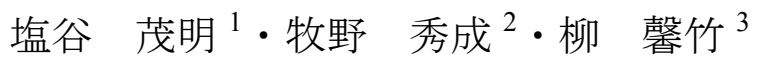 \\ ${ }^{1}$ 正会員 神戸大学教授 自然科学系先端融合研究環（干658-0022 神戸市東灘区深江南町 5-1-1） \\ E-mail:shiotani@maritime.kobe-u.ac.jp \\ 2 正会員 神戸大学学術推進研究員 大学院海事科学研究科（干658-0022 神戸市東灘区深江南町 5-1-1） \\ E-mail: makino@port.kobe-u.ac.jp \\ 3 神戸大学博士課程前期課程学生 大学院海事科学研究科（率658-0022 神戸市東灘区深江南町 5-1-1） \\ E-mail: xinzhuhaha@live.cn
}

\begin{abstract}
様々な航海情報は, 航海の安全性確保に非常に重要である。航行船舶の安全性は常時海難防止のために 要求されている。海難発生要因の第一位は衝突, 第二位は乗り揚, 等と続く. 特に, 海難発生海域は陸地 に近い沿岸海域であり，特に浅瀬部分に多い。これらの海域では, 海難防止に役立つような様々な航海情 報の効果的な提示が, 極めて重要である. また, 航行船舶の海難防止に有益な航海情報の有効な表示も重 要である.

このような背景から，本研究の目的は，沿岸域航行船舶の海難防止に有益な航海情報の表示について， GISを用いて提案すること, さらに道路交通では既に多数利用されているカーナビゲーションの海上航行 船舶での利用の適用性について論じることである.
\end{abstract}

Key Words : Safe navigation, navigation information, car navigation, marine traffic, GIS

\section{1. 緒言}

航行船舶の安全性確保を目的に, 船体構造や運動性能 の改良及び様々な最新鋭の航海機器の搭載等が進められ てきた ${ }^{1)}$. しかし，海上保安庁の統計によると，この 10 年間, 船舶の海難発生件数はそれほど減少していない ${ }^{2)}$. むしろ, 今後船舶数の増加に伴い海難の増加が懸念され る.

著者らは海難の減少を目差した航海の安心・安全支援 を目的に，様々な航海情報の有効かつ適切な提示に関す る研究を進めてきた. 現在利用されている航海情報は, 紙媒体の海図や画面上にデジタル表示された ECDIS(電 子海図)がベースである ${ }^{3)}$. 著者らの航海情報の提示は, 航海士が船橋で見る景色を, より現実的に画面表示し, それに様々な航海情報を重衫合わせる ${ }^{4,5}$ ， これらの航 海情報の提示は, GIS を用いた二次元及び三次元の地理 情報システムに基づいている 示の海図は，新しい航海情報の提供概念である，道路交 通では，すでに自動車のドライバー用の支援装置として カーナビが利用されている。 しかし，海上交通では未だ 十分開発されていないのが，現状である.

本研究の目的は, 海図を補足する航海情報の表示法の 提案と共に, 自動車専用のカーナビを船舶に搭載し, 航 海情報の提供法の改良を行うことである. 近年，カーナ ビは急速に発展し, 性能も飛躍的に発達している，カー
ナビの海上での利用による有効性や問題点なども抽出し, 航海情報の提示の開発を行うことである.

\section{2. カーナビの利用}

\section{(1) 供試船と試験機器}

著者らによる沿岸海域航行船舶の安全性支援が目的の 航海情報提供の研究では, カーナビ, 携带用の AIS 及び ビデオカメラを小型船舶に搭載し，カーナビの性能と海

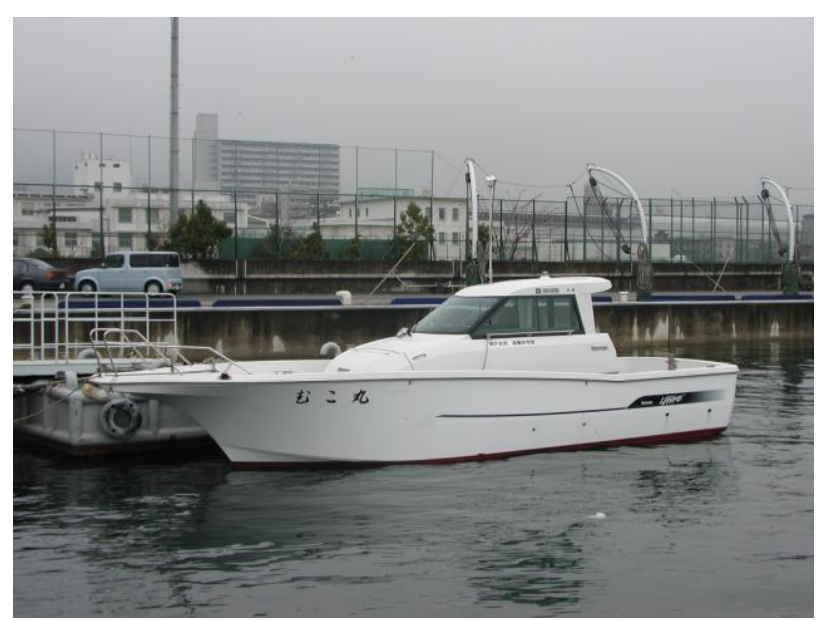

図-1＼cjkstart供試船「むこ丸」 
表-1 むこ丸の主要項目

\begin{tabular}{lr}
\hline Item & Mukomaru \\
\hline Lpp (m) & 9.33 \\
B (m) & 2.54 \\
D (m) & 0.89 \\
$\Delta$ (ton) & 3.4 \\
V (knot) & 30 \\
Pw (HP) & 270 \\
\hline
\end{tabular}

上の利用について調査した. AIS は小型船舶の船位取得 が目的である. ビデオカメラは航行周辺海域の景色の撮 影用である。

供試船の小型船舶は，神戸大学大学院海事科学研究科 付属練習船「むこ丸」である. 図-1 にむこ丸の全景, 表-1 に船体主要項目を示す.むこ丸はプレジャーボー トであり，学生の操船実習や周辺海域の調査研究に利用 されている. 図-2 に船舶に搭載のカーナビを示す. カ 一ナビはサンヨー製の SSD ポータブルナビゲーション (品番 NV-SD760FT)で，通称 Gorilla と呼ばれている.

図-3 に搭載した簡易型 AIS 表示システムを示す.ア ンテナからの受信信号を PC に保存し，航程の線を求め た.

\section{(2) 道路上のカーナビ機能}

カーナビの性能及び基本的な機能の把握を目的に，自

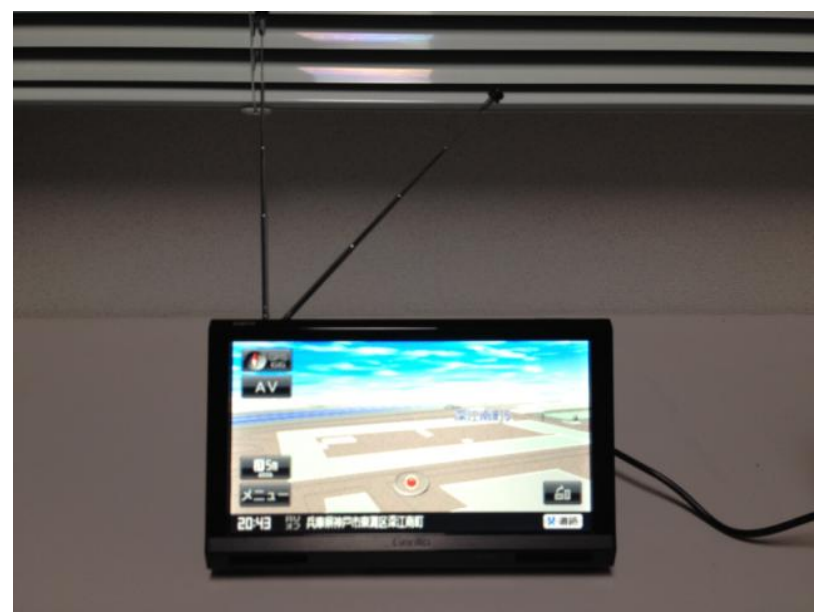

図-2＼cjkstart試験に用いたカーナビ

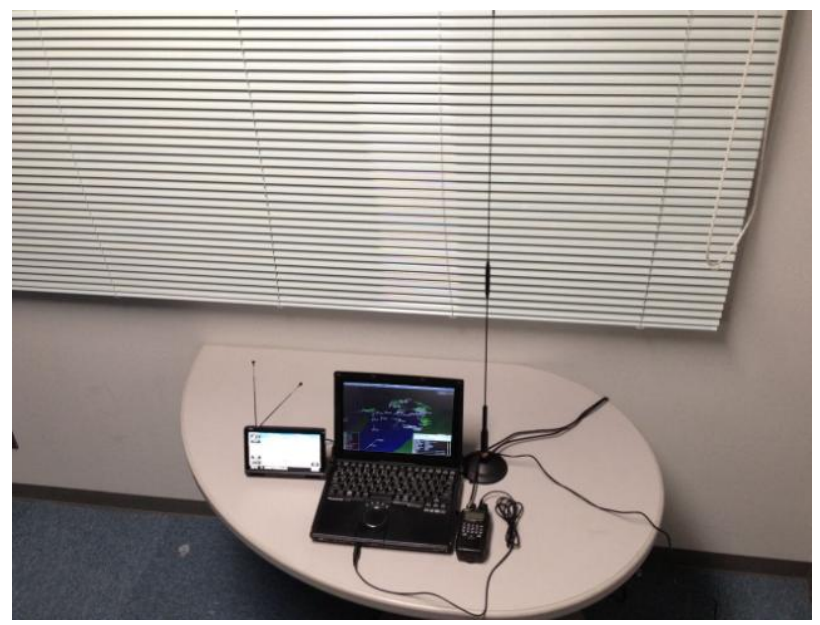

図-3＼cjkstart試験に用いた AIS 機器供試船「むこ丸」

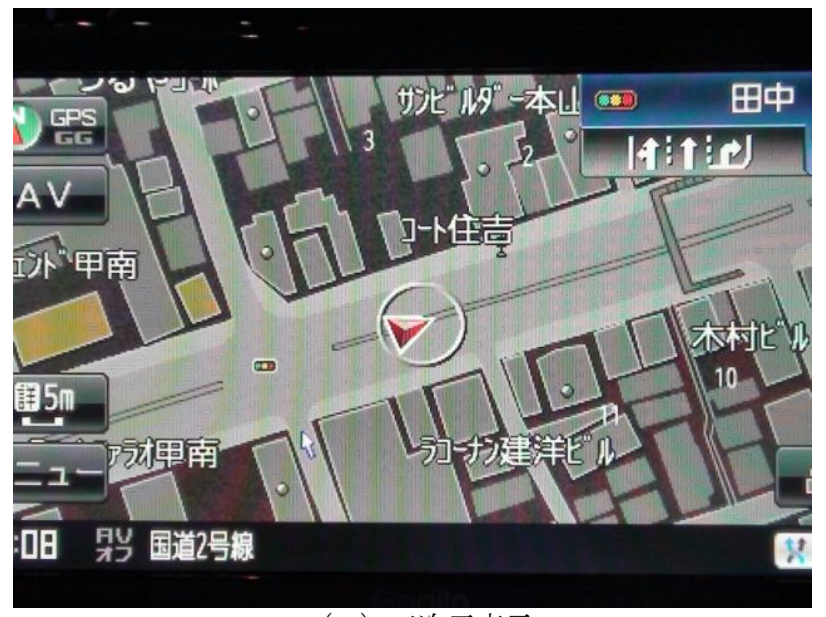

（a）二次元表示

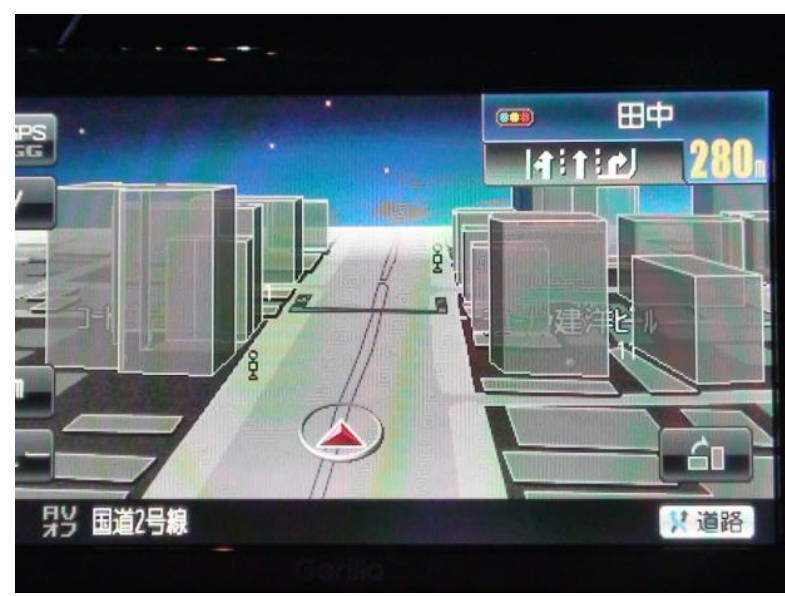

（b）三次元表示

図-4 道路上のカーナビ表示

動車にカーナビを搭載し，道路上を走行した。

図-4 に道路上のカーナビの一般的な表示を示す.

（a ）困は二次元表示である，道路上の三角印が自動車 の位置, 三角形頂点が進行方向を示す．道路に隣接の建 物の形状が詳細に表示され, 顕著なビルの名称が記載さ れている. 画面の左下に通行中の道路名，右上に，交差 点情報として，前方の信号のある交差点でのルートが表 示されている. また，交差点の信号の有無，陸橋等，各 種の運転に必要な道路周辺の地形情報が記載されている. これらの情報は理解度が高いと思われる。

(b)図に三次元表示を示す。運転席から見える顕著な ビル群が立体表示され，自動車の現在位置の確認等がリ アルに出来，運転補助の支援装置として有効である。ま た，バス停の表示も位置確認の把握を助ける。しかし， ビルは直方体であり，色，空，詳細な形状が不明瞭であ り，現実的でない，常時通行する既知の道路であれば， この程度でも理解できるが，初めて通行の道路では，走 行中の道路周辺の理解度は低下寸ると思われる。一層現 実的な詳細な情報が必要であると思われる.

以上により, 改良点も指摘されるが, 道路上の自動車 運転に際し，カーナビによる二次元および二次元情報は ナビゲーション機能として高く評価できる.

3. カーナビによるシ一ナビ 
本来力ーナビは道路上での使用が目的であり，道路交 通に関する情報が記載されている．海上での利用では， 陸地が見えない大洋航海には適さず，陸地が見える範囲 内の沿岸域の航海に限定される。しかも，陸上の建造物 等が視認できる，沿岸に極く接近した航行海域で効果的 である．特に，船舶の輻輳度が高く，地形が複雑な湾岸 や水道等の航行に適する.

図-5 に船舶搭載のカーナビの機能調査を行った供試 船の航跡を示す. Google Earth 提供の衛星写真上に，供 試船の AISによる位置データを重ね合わせ表示した。供 試船は，神戸大学大学院海事科学研究科深江キャンパス 内のポンドを出向し，神戸港内を沿岸に沿って西航した。 六甲アイランド北岸を通過後，ポートアイランド北岸付 近で，迂回した。往路と同じ航路を東航し，深江沖を通 過後，芦屋運河を通り，夙川河口付近で帰航した。

図中の中央部が六甲アイランド，左下端部がポートア イランド，右上端部が夙川河口沖である.

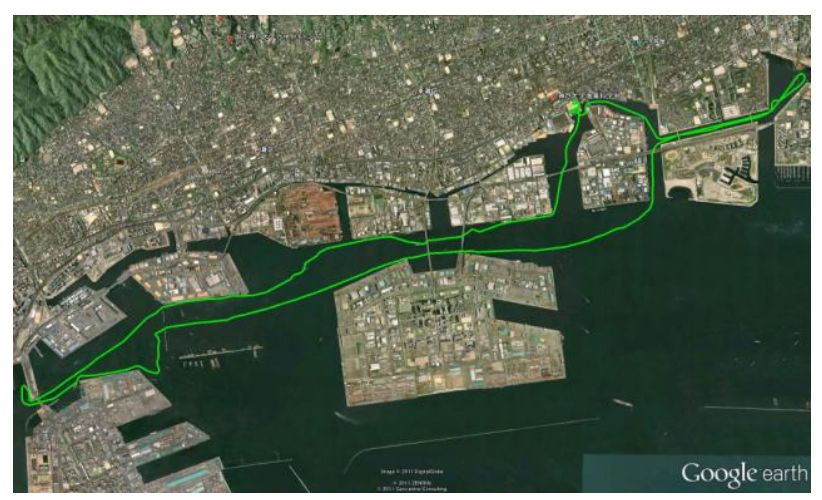

図-5 試験航海の航跡

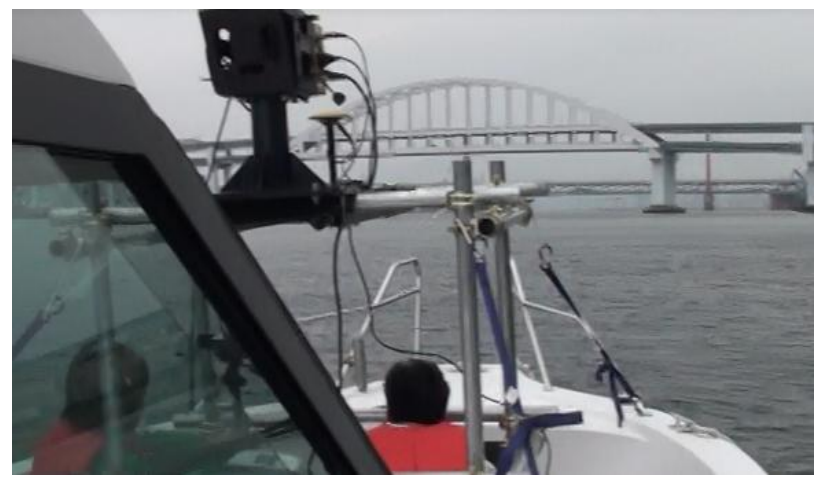

（a ）六甲アイランドに架かる六甲大橋

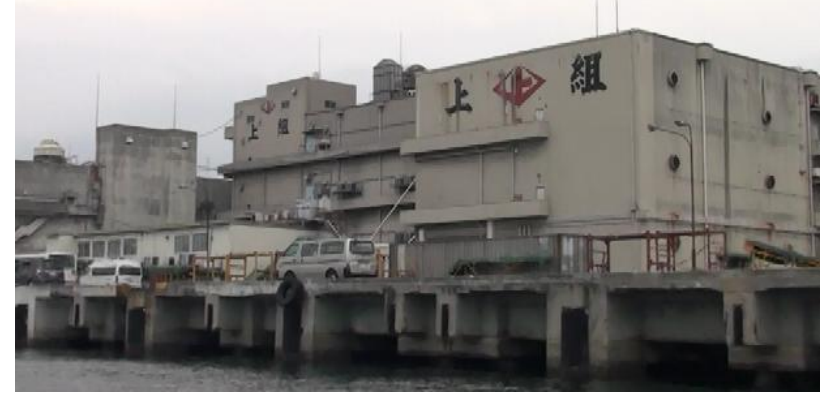

（b）水際の倉庫群

図-6 六甲大橋付近航行周辺海域のビデオ映像

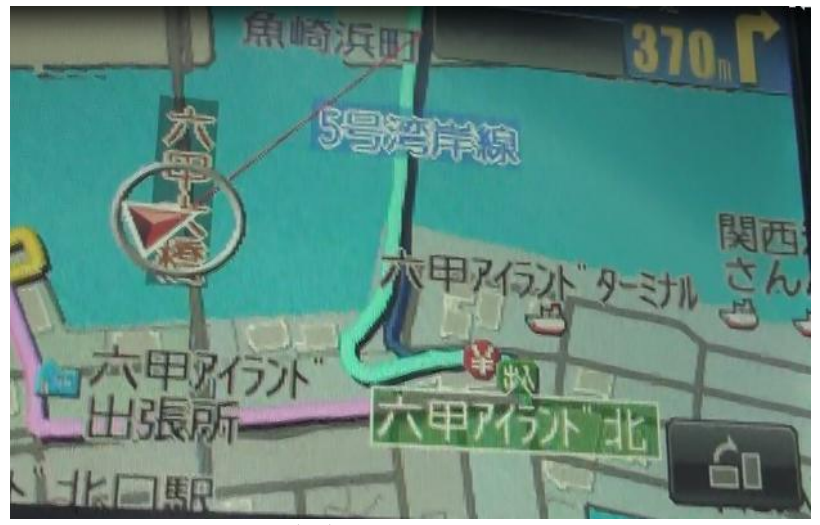

（a ）二次元平面表示

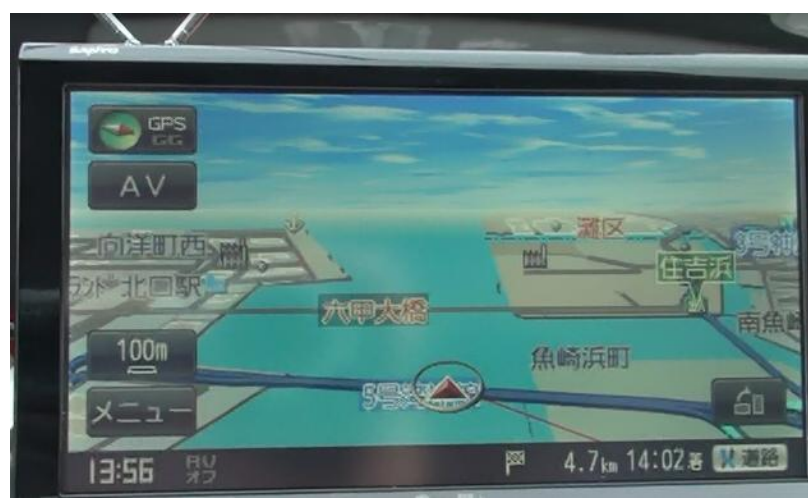

(b) 三次元立体表示

図-7 カーナビによる六甲大橋付近の表示

供試船の速力は，機関の回転数が約 1000 回転の, 約 6ノットである，供試船はプレジャーボートであり，最 大船速 30 ノットまで出力が可能であるが, 高速航走で は，船体の上下動が激しくなり，ビデオカメラの映像の 手ブレが激しく，安定した映像を得ることが困難である.

図-6に六甲アイランドに架かる六甲大橋付近航行時 のビデオ映像の画面を示す．写真(a)が船首前方の六甲大 橋, 写真(b)が航行海域周辺の倉庫群を示す。六甲大橋 が架かる海域の両岸には，船舶が接岸可能な岸壁があり， 海運・運輸関連会社の倉庫群が連なる．航行中の水路幅 は約 $300 \mathrm{~m}$ である.

図-7 に六甲アイランドに架かる六甲大橋付近を航行 中のカーナビによる映像を示す。写真中央下部の三角形 が船位，それから伸びる細線が針路である．写真(a)は二 次元平面図，(b)は三次元立体図である，橋の名称，陸 上の主要地名が記述され, 操船者にとって, 現在位置が 容易に把握出来る. また, 海域周辺の地図が鮮明に示さ れ, 地形の理解度が高く, 航行海域の状況が, 十分理解 できる. (a)図では，顕著な建物の位置が数力所に表示さ れているが，図-6(b)と同様に，建物の数が少なく，省略 されている.これは，岸壁に隣接の用地が海運関連会社 の敷地であり, 一般車両が通行の公道でなく, カーナビ には不要な情報であるため, 詳細に記載されていないと 思われる。

また，図-6(a)の六甲大橋が，図-7(b)には見られず，六 甲大橋の名称があるが，道路として表示されている．橋 を走行の自動車にとって, 橋の詳細な全景は交通情報と して, 必ずしも必要でない. しかし, 海上交通では, 橋 


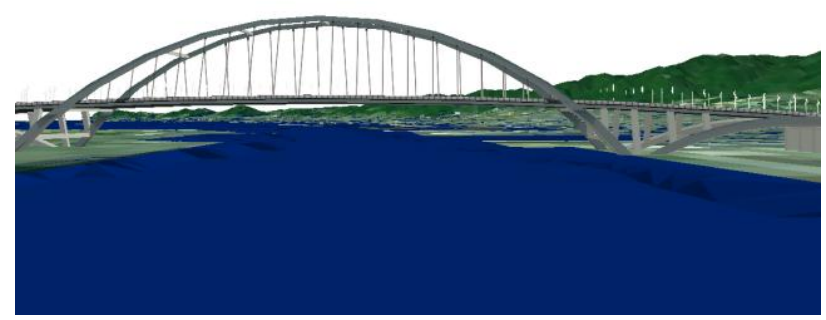

図-8 GIS で作成の明石大橋

と橋脚は物標確認や航路選定に重要な航海情報である. もし，これが海底トンネルの場合，カーナビでは道路と して表示されるが，海上交通では，状況次第では，橋と して誤解されこともあり，船舶の航行には不要な情報で あると思われる。

図-8 に著者らが開発の航海シミュレーションで，GIS 上に作成した六甲大橋を示す．三次元モデルを ArcGIS と整合するソフトウェアの SketchUp を用いて作成し, ArcGIS 上の衛星写真に重ね合わせた．著者らの GIS を 用いた航海支援装置では，衛星写真の地形に，個別に作 成した橋，建物及び航路標識を GIS 上で，重ね合わせる ことが可能である. カーナビの場合も，橋の三次元図を 重ねることが出来れば，海上での利用は有効であると思 われる。

また，図-8 には，灯台や浮標等の航路標識，顕著な 物標, 推薦航路, 水深, 海底の底質など, 航海に必要な 情報が記入されていない。これらの情報も道路交通では 不要であるが，海上交通では重要である.

次に，カーナビと電子海図を比較検討した．図-9に 航行海域周辺の電子海図を示寸. 地形, 水深の数值, 灯 台や灯浮標の航路標識等の航海情報のみしか記入されて いない. 表示される情報量は少ない, 通常, 操船者は紙 媒体の海困から，基本的な航海情報を得る。海図には水 路困誌に表記の様々な航海に必要な有益な情報が，記入 されている. 電子海図の場合, 航海に必要な航路標識等 の詳細な情報は，航路標識をクリックすると，右端に文 字盤が表示され，標識名，塗色，灯質などの簡単な情報 が提供される. 小さな画面に海図のように全ての航海情 報を表記すると，煩雑で見難い理由による.

航海に関する情報量を除き, カーナビと電子海図の地 形に関して比較すると，ほとんど差がない.むしろ，陸 地や建物の名称はカーナビの方が多く, 理解し易い.

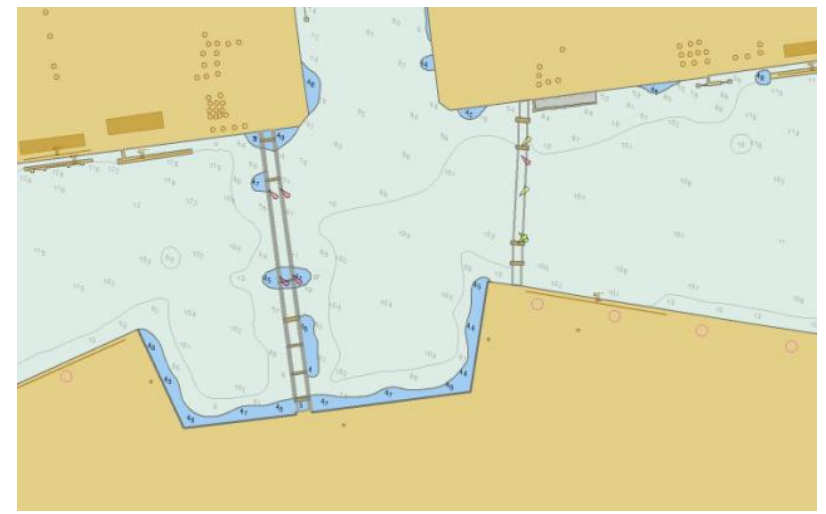

図-9＼cjkstart航行海域付近の電子海図の表示

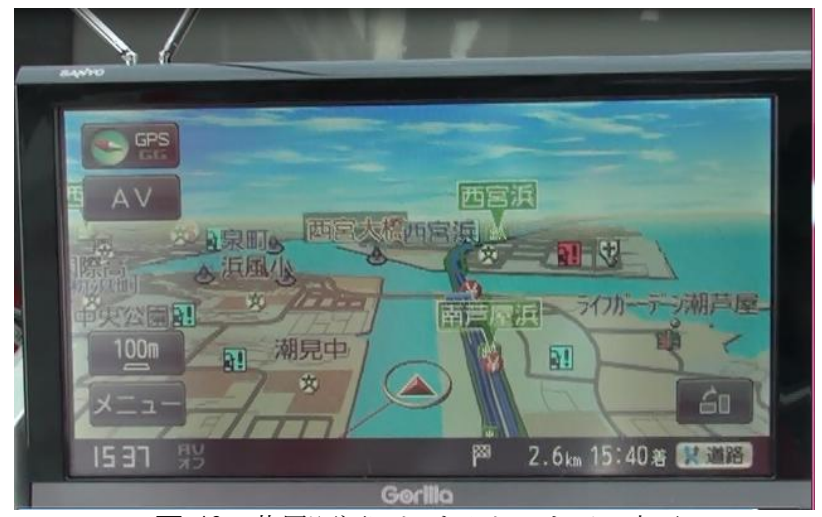

図-10＼cjkstart芦屋運河におけるカーナビの表示

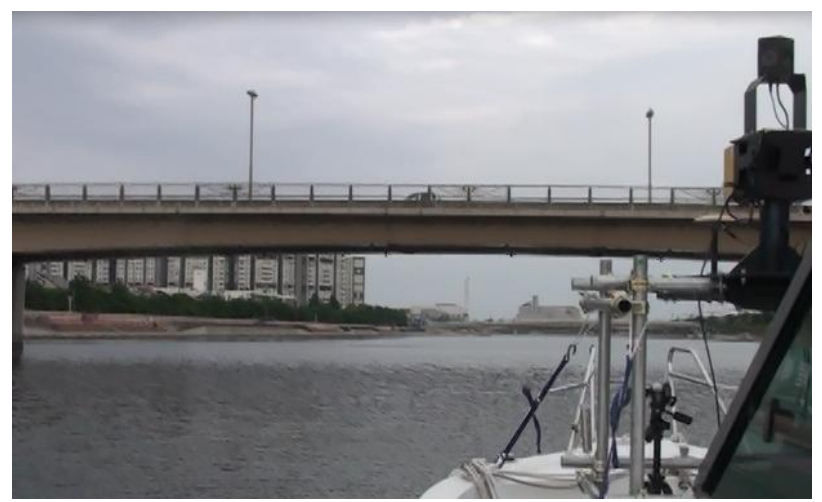

図-11 芦屋運河の船上からのビデオ映像

著者らが開発した航海情報提示システムには，気象・ 海象の航海情報の提示があるが，カーナビには記載され ていない. 現在，カーナビにこのような機能を有する機 器はない. 海困には潮流の平均流速ベクトルが簡単に提 示されているのみであり，著者らが提案する GIS 情報は， この点に関して有効的である.

図-10 に芦屋運河を航行中のカーナビの三次元表示を 示す.また，図-11 に船上からの船首前方のビデオカメ ラの映像を示す．両者を比較すると，ビデオ画面は，船 上で操船者が見る景色とほとんど同じである。しかし， 見える視野は狭く, 建物の後方の景色は当然見えない. しかし，カーナビでは，船首遙か前方の通常では見えな い海域も把握でき，これから航行する船首前方の景色が， 容易に理解できる.しかも，顕著な建物が三次元で表示 され, 地名も一般の地図を見るように平易であり, 海図 の情報より理解し易い.これは芦屋運河の幅が約 $100 \mathrm{~m}$ 程度と狭く，しかも岸壁沿いまで民家があり，道路網も 整備されている. そのため, 両岸の地図上の道路網や道 路情報が詳細に表示されている.

また，目視やビデオ映像では，霧中，雨天の場合，周 辺の景色が見難く，危険であるが，カーナビでは晴天と 同様の情報が提供される，さらに，夜間でも，日昼と同 様に鮮明な景色を得ることが出来る，逆に，日中に夜間 の景色を再現できる.

以上から，カーナビの情報を，電子海図，ビデオ映像 の表示と比較すると, カーナビの利用は航海の安全の支 援機器として, 鮮明な三次元表示が可能であり, 道路上 での自動車の運転感覚で, 海上での操船が可能である. このように, カーナビの利点, 久点を把握した上で，平 
面的な二次元情報の電子海図などの補助としての利用が, 有効的であると考える.

現在，カーナビは数万円程度と安価に購入可能であり, 通常の航海計器と比較すると相当低価格である. そのた め，プレジャーボートなどでは，船上に搭載すると，十 分効果的であると思われる.

\section{4. カーナビ機能のシ一ナビへの適用}

カーナビの機能をさらに詳細に調査し，船舶用のシーナ ビとしての利用の特性を調査した。これは，著者らが現 在研究を進めている，GIS を利用した航海支援システム にカーナビの利点を導入し，高度化を図ることが目的で ある．GIS では，多様な航海情報を重ね合わせた表示が 可能であり，用途に見合った，詳細かつ有効的な航海情 報の提供が可能でなる．この GIS 上に，カーナビの利点 を重ね合わせると，より効果的な情報提供が可能になる。

実験で用いたカーナビの，海上への利用に関連した主 な機能の調査結果を列挙すると, 以下の通りである ${ }^{8)}$.

1)自律航法（本機内蔵のジャイロセンサーと加速度セ ンサーで車の移動方向を判断し, 現在地を推定する. ) とマップマッチングで, GPS 衛星電波の誤差によって起 こる，実際の現在地と地図上の現在地とのズレを，少な くする.

プレジヤーボート等は自動車と同様に，高速と低速航 行を繰り返す操縦もあり, 誤差のズレを少なくする機能 は有効的な機能と思われる. 特に港内等の狭い海域での 航行の場合に適する.

2)目的地を指定すると，探索されたルートを表示して， 案内する.

探索ルートは，現在の船舶航行には，ほとんど見られ ない機能である. 気象・海象を考慮し，推薦航路等を組 み合わせた最適ルートの設定と探索が可能な機能は，今 後有効である.

3)電話番号または住所を入力すると, ソフトに収納の データから目的地を探索できる.

一般商船では，入港地の港湾情報などの収集に役立つ。 また，プレジャーボート等では，不特定多数の小さな漁 港等への寄港もあり，港の情報探索の利用度が高まると 思われる.

4)ビルなどの施設（物件）にカーソルを合わせると， 地罒画面上にビル名が表示される. 設定, さらにテナン ト情報をタッチすると，テナント情報を見ることができ る.

既に，この機能は著者らの航海支援装置に適用されて いる. 一例として, 顕著な灯台や灯浮標等の航路標識を クリックすると, 標識の灯火, 灯質, 塗色, 形象物, さ らに実物の写真等の，詳細な情報提供がされる．航路標 識以外にも航海情報の提示を付加すると, 一層有効的で ある.

5)パソコン上から指定 Webサイト(NAVI)にアクセスし て, SD カードへ地点やルートを保存でき，再び，本機 に表示が可能である.

SD カード等へのルート保存は, シーナビでも, 航海
の記録保存，再現用に必要である。ログブックの補助機 能として有効である.

6)目的地に着くまでルートの探索ができる，2)と関連 し，航海中のルート探索，修正ができると，最短時間や 最小燃料消費量等の最適航法が可能になる.

7)交差点の名称，高速道路の出入り口，路線名，ジャ ンクション等を音声でガイドする.

船舶では，交差点はないが，変針点，入港，進入及び 横断航路までの距離，予測時間等を音声で予告できると， 事前対処ができ，有効である，著者らの航海支援装置に も，音声の導入は検討中である.

8)高速道路の主要分岐ポイント，ジャンクション，ラ ンプの出口に接近すると, 立体的な拡大図を表示して, ルートを案内する.

入出港，指定航路の航行に際し，三次元地形の表示は， 航海のイメージ造りに役立ち，緊張感を和らげ，航海の 支援となり，航海支援装置に有効である。

9)目的地までのルートを，違った条件（推奨ルート， 有料道路優先, 一般道路優先, 距離を優先, 道幅を優 先）で一度に探索できる。

航海時間，燃料消費量，待ち時間最小，安全性重視な どの選択肢により，航路選定の探索が出来ると，有効で ある.

10)ルート案内時, 国道や，一般道の行き方や方向を 示す案内標識(看板)を表示させることができる.

明石海峡や狭水道通過時に，航海に関する一般的注意 や導墝用航路標識などの表示は，航海支援装置でも効果 的である.

11)ルート案内時, リアル $3 \mathrm{D}$ 交差点を表示する.

変針点，狭水道，目的港に接近寸ると，船上から見え る周辺海域の三次元景色の表示があると, 航海の確認が 可能になり, 安心感が向上する.

12)都道府県市街地図収録エリアで，ビルなどの建造 物をリアルに立体表示することができる.

航海の物標となる建物や航路標識等の立体表示により， 形象物の効果的な確認ができる.

13)文字, 図形, 地図表示で渋滞情報サービスを受け ることができる.

海上交通情報センター等から，船舶の輻輳度や渋滞情 報の提供表示は，航海の安全支援に役立つ.

14)一方通行の規制を道路上に表示する.

来島海峡等の法的規制のある特定航路通行に際し，詳 細な規制を文字盤，図形表示により，航海士への再確認， 注意喚起ができる.

15)上空より進行方向前方を見下ろす角度で，現在位 置周辺を表示する.

自船の航行状況を，三次元鳥瞰図で船舶を見ると，周 辺海域状況の一層の把握に役立つ. 特に, これから航行 しようとする船首前方の, 周辺海域の状況把握が可能で あり，これらの機能を既に採用している。

16地図の色を選ぶことができる.

色分け，色の濃淡の選択により，地形がよりリアルに 表現できる．航海支援装置では，海底地形や等水深線の 表示に，既に採用している.

17)本機のフラシュメモリー内に，音楽ファイル，画 
像ファイル，動画ファイルをコピーして再生することが できる.

航海情報や航海シミュレーションに音声，画像，動画 の導入表示したファイルを，航海中に再生することによ り，航海に必要な様々な情報の再確認，学習が有効に出 来る.

18)本機内蔵の地上デジタルテレビ放送用チューナー で，地上デジタルテレビ放送を受信できる.

航海中にテレビから最新の天気予報やその他の情報収 集が可能であり，航海に有効である.

以上，カーナビの機能の調査から，現在提供の情報に， 航路標識，航路，底質，等水深線など，海困に記載の 様々な航海情報を付加し，航海用にアレンジすると，よ り高度な航海情報提供のシーナビに変換できる。また， 著者らの研究する航海支援装置にカーナビの機能を付加 すると，一層高度化できることがわかった.

\section{5. 結論}

著者らは，航海の安心・安全性の確保を目的に，適切 な航海情報の提供法に関する研究を進めている．道路交 通に使用されているカーナビを，船舶の航海用のシ一ナ ビとしての利用の適用性について調査した。適用評価は, 紙媒体の海図や電子海図，ビデオ映像，GIS を利用した 航海情報支援装置との比較により行った。

その結果，以下の主要な結論を得た。

1)カーナビは三次元地形の情報提供が可能であり，海図 にない視覚的効果がある. 三次元海図が作成出来ると, カーナビと同じ利用が可能になる.

2)カーナビは GPS を搭載し自立航法とのマッチングで, 精度よい船位が得られ，自動プロットが可能であり，針 路，船速等の表示が可能である.

3)カーナビは道路走行中に，車上から周辺地域の地理情 報が得られる．海上でも，同様の周辺海域の地図情報の 提供が，通常海図より詳細な情報が得られる.

4)カーナビの表示には，灯台，航路標識，水深情報等の 航海に必要な情報の提供はされない。もし，これらの航 海情報をカーナビに付加すると，シーナビとしても十分 利用可能になる.

5)著者らが研究中の，航海支援システムに，カーナビの
機能を導入することにより，高度な航海情報の提示が可 能になることがわかった。

以上から，カーナビに多様な航海情報を付加するか， あるいは航海支援装置にカーナビの機能を付加すること により，一層高度な航海情報の提供が可能になる。今後, さらに航海情報の有効な提示に関する研究を進める所存 である。これにより，航海の安心・安全性の向上が高ま るものと思われる。

本研究は，科学研究費の基盤研究（B）の「海の ITS を利用した数值ナビゲーションシステムによる海難防 止」(課題番号 22310100)の一環として実施したことを付 記する。

\section{参考文献}

1)今津隼馬, 藤坂貴彦, 福戸淳司, 大竹裕一郎 : 航行情報の統 合と表示に関する研究, 日本航海学会論文集, 第 109 号, pp.133-140, 2003.

2)海上保安庁 : 海難及び人身事故の発生と救助の状況, pp.16-19, 2007.

3)若林伸和, 矢野吉治, 林祐司, 村井康二 : IP ネットワークを 利用した航海データ収集・転送システムの開発 練習船深江 丸における実装一，日本航海学会論文集，第 106 号，pp.2937, 2002.

4)塩谷茂明，牧野秀成，嶋田陽 : 沿岸海上交通の海難方止の ための航海情報支援に関する研究一水深情報一，土木学会 論文集 D3(土木計画)，2011.

5)塩谷茂明, 牧野秀成, 永吉優也, 柳馨竹 : 沿岸航海の安全の ための航海シミュレーションに関する研究，土木学会論文集 D2(海洋開発)論文集，Vol.67,No.72,pp.I_838-I_843,2011.

6)川崎昭如 : 図解! ArcGIS Part2 GIS 実践に向けてのステップア ップ, p.174, 古今書院, 2006.

7)佐土原聡 : 図解 ! ArcGIS 身近な事例で学ぼう, p.176, 古今書 院, 2005 .

8)三洋電機株式会社 : 取扱説明書 SSD ポータブルナビゲーショ ン品番 NV-SD760FT, p.A-14-A-38.2011.

\title{
STUDY ON NAVIGATIONAL INFORMATION AND APPLICATION OF CAR NAVIGATION FOR SAFTY OF A SHIP SAILING IN COASTAL SEA AREA
}

\author{
Shigeaki SHIOTANI, Hidenari MAKINO and Shinchiku RYU
}

\begin{abstract}
The information on navigation is very important for safe navigation. The safety of a sailing ship is demanded for the prevention of a marine disaster. The causes of a marine disaster are collision, stranding of a ship and so on. Especially, the most of marine disaster causes in the shallow water relatively of the coastal area. It is very important to propose the effective information of navigation for the prevention of a marine disaster. Also, the information of navigation which supports the safety of a sailing ship is demanded. The present paper proposes the effective presentation for information of navigation using GIS and the efficiency of a car navigation used by the road traffic is examined for prevention of a marine disaster.
\end{abstract}

